энцефалитъ. Ивфильтрація оболочекъ эмбріональными кльтками, періартеріить. Разращеніе нейрогліи въ моллекулярномь слоб. Лимфоциты въ периваскулярныхъ пространствахъ; гіалиновыя тьльца. Инфильтрація оболочекъ мозжечка. Склерозированы пирамиды; раялитой менингить оболочек' bulbus. Грануляціи съ пучками вейроглійныхъ фпбрилль на днб 4 желудочка. Авторъ предполагаегъ, что дыло идеть о сифилитической эпилепсіи, по Fournier, въ виду того, что әпилептиqескіе кризы исчезали на 5 льть до развитія прогрессивнаго паралича; симптоматическую же форму кривовъ первоначальн обусловливали хроническія кортиғальныя измњненія. Рњдкость такого факта авторы ставять въ зависимость оть рбдкости сифилиса у женатыхт.

Пренія: Pactet, соглапаясь съ мнсніемь авторовъ, рьдкость діагноза разбираемыхъ случаевъ приписываеть медленности теченія процесса и недостаточной поднот Briand, Marchand $и$ Arnaud придають сифилису значевіе в'ь этіологіи забольванія. Vallon требуеть изученія тавихъ случаевъ въ заведеніяхъ для эпилептиковъ, а не въ общихъ лечебницахъ, гд' әтихъ больныхъ мало.

A. $X$.

„Современная психіатрія“, январь, г9о8 г.

Д-ръ Сухановз въ стать' „О конституціовальныхь психопатіяхъ и психозахъ“ даеть раздъленіе видовъ прирожденной нервно психической организаціи, различая психоастеническую, истерическую, эпилептическую и патолого-резонерскую конституціи. Психоастеніи свойственъ тревожно-мнительный харавтеръ, на почвъ котораго обнаруживаются извьетныя навязчивыя психическія состоянія.

Истерія развивается обыкновенно, какт страданіе сь самаго начала врожденное, - на основ' соотвйтственной конститудіи. Весьма въьроятно также, что эпилептическій судорожный припадоєь есть лишь частный и необязательный сим птомь конституціи әпилептическов̈, проявляющейся опредьлегвыми чертами хараћтера. Патологическое резонерство типично для тавого рода духовной организаціи, на почвъ которой, въ дальньйшемъ, можеть развится тоть или иной видъ paranoiae, шзъ формъ резонирующихъ. Всь угазанныя „вовститудіп“ 
могуть перейти границу просто „харавтера“ и стать „цсихопатіями ,

Д-ръ Образиовъ въ стать' „вь симптоматологіи алвоголизма “ разсматриваеть четыре случая из' своей правтики, когда-согласно даннымъ Rodiet и Gans'a-замьчалось любопытное и еще малоиввьстное явленіе, именно, неодинавовость тактильныхъ воспріятій ва различныхъ половинахъ глазныхъ яблокъ. Явленіе это, можеть быть, стоптъ въ связи съ состо яніемъ кровообращенія въ лиць.

Дръ Гаккебушб въ отдьвы „Корреспондевція“, предлагаетъ, на основаніи принципа децентрализаціи, свой планъ обслуживанія психіатрической помощью населенія Харьковской губоерніи.

И. Жилинг.

\section{Tepa пія.}

Dr. Felix Mendel. Л安ченіе фибролизиномъ и его ревультаты. "Новое въ Медицин'ь“. №o I, 2, 3. 1908.

Фибролизинъ представляеть собой двойное соединевіе тіовинамина и салициловаго натрія, легво растворимое вь водъ. Область примьненія фибролиянна -забольванія, сопровождающіяся развитіемь фоиброзной, интерстидіальной твани. Въ этихъ случаях' фибролизинъ вызываеть „разрыхленіе плотныхъ воспалительных' тяжей и размягченіе отложившихся патологическихъ продуктовъ, благодаря котсрому облегчается ихъ разсасываніе“. Прим'ьвяется фибролизинъ въ форме внутримышечныхъ ивъэкціи, совершенно безбол'ьзненныхъ, возщожны также подқожныя и внутривенныя вспрыскиванія. Доза для взрослыхъ- 2,3 раств. фибролизина, для дътей-не меньmе половины этой дозы; число ин'ьэвціи волеблется, смотря по случаю, между 5-ью и 50-ью. Побочныхъ дьйствій почти не наб̆людается Длинный перечень забольваній, пользованныхъ съ усп穴хоз фибролизиномъ, закончивается указаніем' на, привосходный результать“, достигнутый при льченіи инъекціями фибролизина хроническихь невритовъ, обусловленныхъ жатолого-анатомически хроническимъ периневритомъ и уже не подлававпихсд другимг способамь терапіи.

И. Жилинг. 